\title{
Promises and Contests of Participatory Forest Management (PFM) Scheme within Kafa Biosphere Reserve, Southwest Ethiopia
}

\author{
Befikadu Melesse Taye \\ Department of Geography and Environmental Studies, Wolkite University, Ethiopia
}

\begin{abstract}
The PFM scheme; where the community-based natural resource management has been receiving growing scientific attention over the past three decades. Most studies, however, focus on investigating institutional designs and outcomes and pay scant attention to how community-based natural resource management arrangements are carried out in practice. Therefore, this study focused to examine the possible promises with the establishment and actual practices of PFM scheme and visible contests that needs solutions to sustain the scheme in Kafa forest coffee Biosphere Reserve. To realize this thought 16 PFM sites of five districts of Kafa zone were purposively studied by collecting primary data through focused group discussions with forest management committee members and triangulated site based actual assessment practices with members to be evidenced about the promises and available contests of/on PFM scheme. Through an in-depth survey study in all of the participatory forest management (PFM) sites in Kafa zone, southwest Ethiopia, this article demonstrates a significant promises and contests between the PFM forest management plan and actual local forest management practices. The study confirms the usefulness of a practice-based approach to understand and explain how a newly introduced institutional arrangement is acted upon by local actors situated in their social, political and historical context as promises. On the other hand, the lagging commitment from the government agents, illegal users, uncontrolled forest use pressures and unbalanced commitment among the forest user group were proved as greatest upcoming contests on the sustainability of Kafa forest coffee Biosphere reserve in general and PFM of each site in particular. The findings also contribute to empirical knowledge useful to initiate dialog and to critically reflect on whether and what kind of intervention is actually needed to positively influence forest management practices on the ground for its sustainability based on the plan.
\end{abstract}

Keywords: PFM arrangement; promises and Contests of PFM; practice-based approach

DOI: $10.7176 / \mathrm{JRDM} / 65-01$

Publication date:May $31^{\text {st }} 2020$

\section{Background}

The afro-montane coffee forests contained within the UNESCO Kafa Biosphere Reserve in the Southwest of Ethiopia represent some of the country's last remaining cloud forests (Ben DeVries et al, 2012). These forests therefore represent an important national carbon store managed by the local communities with shared responsibilities with the government based on forest management plan at each PFM sites (Alemayehu et al, 2015). The system, participatory forest management (PFM) was introduced in Ethiopia around the mid-1990s as a new system of forest governance. PFM was meant to avert the persistent problems of deforestation and to deliver better social and economic outcomes compared with the former centralized command-and-control resource management approach (NABU, 2010). In the Ethiopian context, PFM is recognized as a co-governance institutional arrangement where forest management responsibilities and use rights are legally shared between a government agency and a community-based organization (CBO), such as forest user groups or forest cooperatives (Winberg, 2010). The inception of PFM in Ethiopia was considered a radical departure from the centralized and technocratic forest management style to a more inclusive arrangement.

The centralized approach of the State adopted by the successive governments in Ethiopia to manage and develop forest resources appeared not compatible with communities' perception of access rights to forest products and their demands for forest ownership (Alemayehu et al, 2015). With continued population pressure and forest degradation, the approach also undermined the roles of local communities, their traditional institutions and knowledge in forest management practices, and considered local communities as enemies (destroyers) of the forests (GOBEZE, 2009). Without the legal recognition of the right to use forest products, local people have neither the interest nor the courage in protecting and developing forests. Such systems would rather generate an incentive structure that force locals to irresponsibly exploit forests. Hence, the centralized forest resource governance by the last successive governments also failed to allocate sufficient human and economic resources to sustainably manage nationalized forests. Consequently, forest resources belong to the State de jure but they are de facto open access for all sorts of exploitation.

In sharp contrast with the old 'command and control' system of forest governance, PFM recognizes local communities' stake in managing and improving the condition of the forests, rather than characterizing them as an 
inevitable destructive force. PFM in Ethiopia has emerged alongside a broader global movement towards decentralized forms of natural resource governance (Mulugeta et al, 2015) that try and align environmental protection with economic development.

\subsection{Statement of the Problem}

Almost all the natural forests in Ethiopia were designated state forests until the development of the Forest Development, Conservation and Utilization Proclamation number 542/2007 in the year 2007 which made provisions for the ownership of natural forests by local communities (Tesfaye, 2011) under participatory forest management scheme.

The designs, names and ideas of PFM are as various as the number of implementers all over the world. However, the general and common component is the focus on community participation in forest management. This includes agreeing with government institutions or landowner(s) ${ }^{1}$ on management plans and the sharing of responsibilities, costs and benefits between a given community and landowners (Winberg, 2010). The PFM plan and agreement defines the roles and responsibilities of the communities and the government. The agreement come up with two controversial and significant objectives; biodiversity conservation vs improving rural livelihoods as grand theme (Alemayehu et al, 2015). The first approach is to safeguard the security of forest ecology by mobilizing the community through legal agreement according to the forest management plan. However, it was conflicted with the second theme improving the livelihood of the rural communities. That is why some scholars argued on the scheme pointing that the local communities cannot get benefitted without disturbing the ecosystem and improve their livelihood (Yonas, 2005). Beside these, if improving rural livelihood of the communities proved and the natural biodiversity was rehabilitated through PFM scheme as promises, in the first rank the beneficiaries could only forest user groups who have granted use right according to the forest management plan and the responsible one.

Ironic to this fact there is great need of rural communities who have no use right and increasing expansion of agricultural land, urbanization and pressure from illegal users and forest land based investors ${ }^{2}$. As the consequences of these all in at each PFM sites the contests of forest management is leading than the promises underlined for future base biodiversity conservation and improving the livelihood of rural communities in sustainable manner.

\subsection{Objectives of the Study}

This study was focus on the "exploring the possible promises and examine the contests of existing Participatory forest Management (PFM) sites within Kafa Biosphere Reserve, Southwest Ethiopia";

Specifically: the study focuses to:

* Identify the promising achievements with the establishment of PFM sites within Kafa zone.

* See contests and their underlying causes based on FMP at each PFM sites.

* Forward measures for improved PFM implementation, management and awareness creation to optimize the promises in sustainable manner.

\subsection{Research Questions}

Based on the above specific objectives, this study aimed to address the following research questions.

$\checkmark$ What were the foreseeable opportunities with the establishments PFM sites of Kafa BR?

$\checkmark$ What issues discovered as special contests within the established PFM sites of Kafa BR?

$\checkmark$ What measures should be taken to optimize the promises through reducing or avoiding the visible contests with PFM scheme within Kafa BR?

\section{Materials and method}

After defining the objectives and research questions of the study, the study conducted at each PFM sites of Kafa BR. The study enrolled both primary data collection from members of PFM and local people and government actors and secondary data collection from existing documents at coordinating office (NABU) and district based reports indeed. The main idea to the report was compiled data collected from PFM management committees via structured and semi-structured questionnaires to collect both qualitative and quantitative data. So as to verify the collected data group discussion has been conducted at committee level and feed backs were collected to strengthen the collected information by questionnaires to enrich the study. And the documentary survey has great role for the verification in its part.

\footnotetext{
${ }^{1}$ In Ethiopia according to FDRE - the land is belongs to the government and its citizens have only use right.

${ }^{2}$ In Kafa zone in particular - the private investment sector is coffee plantation agriculture. In some sites forest lands under PFM scheme were under great pressure due to the interest of the private investors.
} 


\section{Discussion and Findings of the study}

\subsection{The promises of Participatory Forest Management within Kafa BR}

\subsubsection{Plan based coordination of different actors on forest management}

As described by different studies Participatory Forest Management scheme in Kafa BR is guided by forest management plan (MoARD F. a., 2010), done through the participation of different concerned government agents, NGOs and local households.

In line with coordinated efforts of different actors the significant successes found in study as findings were; 1) the efforts of NABU and local government integration to manage the existing forest through mobilizing the local community proved pioneer in the PFM scheme. As different reports and key informants of the study confirmed that in PFM site identification within Kafa BR and establishments, approaching the community with detail communication with serious of debates NABU Local coordination office played pivotal role.

As repeatedly stated by forest user groups of all PFM sites of Kafa BR, it was NABU who convinced all members to be committed and stand together by strategic plan; forest management plan (FMP). The plan is unique in character and the first in incorporating females and marginalized Manja people (Alemayehu et al, 2015). Hence, for this society use right was not known before PFM scheme establishments.

Accordingly, with great commitment of NABU coordinating office about 11,538.91ha of forest land with special natural land scape and Non-Timber Forest Products (NTFPs) were demarcated within 16 identified PFM sites were legally transferred to community.

The coordination of all actors was proved with significant planning stages and practical implementation indeed. As the data indicated that numerous indigenous trees were planted and resulted restoration of degraded forestland. In addition to forest development plan, both protection and utilization was given great emphasis among the actors with well-organized institutional make up. The PFM scheme has strong institutional structure from individual role to mass level to secure the whole forest management plan (MoARD F. a., 2010).

Table: 3.1 Basic information on PFM sites by District level at establishment stage

\begin{tabular}{|c|c|c|c|c|c|c|c|c|c|c|}
\hline \multirow[t]{2}{*}{ District } & \multirow{2}{*}{$\begin{array}{l}\text { No. of } \\
\text { PFM site }\end{array}$} & \multicolumn{8}{|c|}{ FUG members of 16 PFM sites within 5 districts } & \multirow{2}{*}{$\begin{array}{l}\text { PFM area } \\
\text { in ha }\end{array}$} \\
\hline & & $\mathrm{M}$ & $\%$ & $\mathrm{~F}$ & $\%$ & $\mathrm{~T}$ & $\%$ & Manja & $\%$ & \\
\hline Adiyo & 4 & 2025 & 48.88 & 2118 & 51.12 & 4143 & 52.12 & 99 & 25.52 & $32.74 \%$ \\
\hline Decha & 4 & 751 & 76.87 & 226 & 23.13 & 977 & 12.29 & 93 & 24.67 & $23.13 \%$ \\
\hline Gesha & 2 & 174 & 61.48 & 109 & 38.52 & 283 & 3.56 & 38 & 9.79 & $6.05 \%$ \\
\hline Gimbo & 4 & 1084 & 54.89 & 891 & 45.11 & 1975 & 24.84 & 117 & 30.15 & $23.26 \%$ \\
\hline Saylem & 2 & 270 & 47.37 & 300 & 52.63 & 570 & 7.17 & 34 & 8.85 & $14.82 \%$ \\
\hline Total & 16 & 4304 & 54.15 & 3644 & 45.85 & 7948 & 100.0 & 384 & 100.0 & 11538.9 \\
\hline
\end{tabular}

Source; NABU proceeding training Report 2013

As shown in the table to manage the forest within 11538.9 ha everyone registered as member has signed to take responsibility on forest management. Here, the participation of female ${ }^{1}$ householder and Manja ${ }^{2}$ clan put the scheme in Kafa BR unique with change and continuity of natural resource management.

The PFM scheme offers opportunities to strengthen social capital and increase community voices of the neglected social groups around resource allocation and decision making that can extend beyond the forest sector. Hence, in the history of forest management starting from planning to implementation of forest management plan householder females and Manjas were incorporated and playing their respective role. Accordingly, in each section; i.e. forest development, protection and utilization part proportional females and Manjas were allocated as executive committee members who were also assigned into sub task oriented category such as, chair/deputy chairperson, clerk, women and minority representation, control and development division, who were legally responsible on PFM functioning.

Hence, PFM scheme come up with these opportunities for forest user groups. All the committee members and forest user members were very happy with the establishment of PFM and well trusted it and looking for more opportunity in the future.

Some forest user groups coined that:

“...by being within the scheme we started planning our land for farming, planting permanent trees and settlement. In addition to these our social belongingness and coordination goes to address social issues like sharing market information, HIV/AIDS, monitoring security issues...etc."

In some PFM sites with strong commitment of executive committee documentation, performance evaluation and feedback reporting on forest status and members participation was assessed and taken as historical at local

\footnotetext{
${ }^{1}$ In some circumstances within polygamy family members the elder wives were recognized to have potential share with her husband while the young one shares half of their husband.

${ }^{2}$ Manja clan in Kafa is socially marginalized and known as man of forest; who leads their live by hunting wild animals and gathering indeed. Now, these peoples were suffering with population pressure on forest and great social marginalization practices.
} 
coordination office level. As to me it is really special and was not practiced by government agents except the area of coverage.

From my field observation, forests out of PFM scheme are at great pressure due to increasing population and forest land transfer for investment. However, the canopy of forest under PFM scheme was rehabilitated and secure as compared to communal one.

\subsubsection{Potential Assessment}

After legal recognition of the forest under PFM scheme, in order to implement the forest management plan in general and protection of forests in particular; therefore responsibility was transferred to the community and woodlands will be reinforced by promoting the sustainable harvesting of indigenous resources, to provide benefits and commercial opportunities to local communities. Government will consider incentives to promote sustainable management of these resources." (Forestry, 1996). The forests demarcated and non-demarcated in Kafa Zone in general have plenty of diverse plant species of which their medical values were not assessed in this study.

The result of the study confirmed that the potential resources of the PFM sites, the FUGs dully confirmed the endowment of Non-Timber Forest Products (NTFPs) such as organic forest coffee, honey, Wild Pepper (Spice), Cardamom as NTFPs and special falls, springs and wildlife indeed. These NTFPs are vital sources of income, great nutritional and medicinal values for many forest-based communities around the world (MoARD, 2013) in genral and Kafa BR in particular.

Table: 3.2 The estimated potential NTFPs produces of different PFM sites by districts

\begin{tabular}{|c|c|c|c|c|c|c|}
\hline \multirow[b]{2}{*}{ No. } & \multirow[b]{2}{*}{ District } & \multirow[b]{2}{*}{$\begin{array}{l}\text { No. of PFM } \\
\text { site(s) }\end{array}$} & \multicolumn{4}{|c|}{ State of estimated potential NTFPs produce from five districts } \\
\hline & & & $\begin{array}{c}\text { Forest coffee } \\
(\mathrm{Kg})\end{array}$ & Honey $(\mathrm{kg})$ & $\begin{array}{c}\text { Cardamoms } \\
(\mathrm{kg})\end{array}$ & $\begin{array}{l}\text { Wild Pepper } \\
(\mathrm{kg})\end{array}$ \\
\hline 1 & Adiyo & 4 & 4900 & 6250 & 200 & 50 \\
\hline 2 & Decha & 4 & 33,000 & 5250 & 500 & 1470 \\
\hline 3 & Gesha & 2 & 0.00 & 13620 & 0.00 & 300 \\
\hline 4 & Gimbo & 4 & 20315 & 10200 & 850 & 340 \\
\hline 5 & Saylem & 2 & 0.00 & 15,480 & 0.00 & 0.00 \\
\hline & Total & 16 sites & 58,215 & 50,800 & 1,550 & 2,160 \\
\hline
\end{tabular}

Source: - Field Survey

As one can examine based on the estimation of forest user groups at each PFM sites, all sites have highly demanded organic products only by participatory forest management plan. These resources were not collected from communal forest or out of PFM sites due to population pressure.

As the forest under PFM scheme was legalized also for resource use right via managing the available potentials NTFPs of the forest (KFCFCU, 2013). On the basis of the potential resources the FUGs were planning to collect the produce without wasting in the future so as to safeguard the forest resource use sustainability.

The study result shows that in all PFM sites by produce potentials of NTFPs the annual yield of coffee comes first and honey comes at second position.

Figure: 3.1 Estimated potentials of NTFPs produce within Kafa BR.

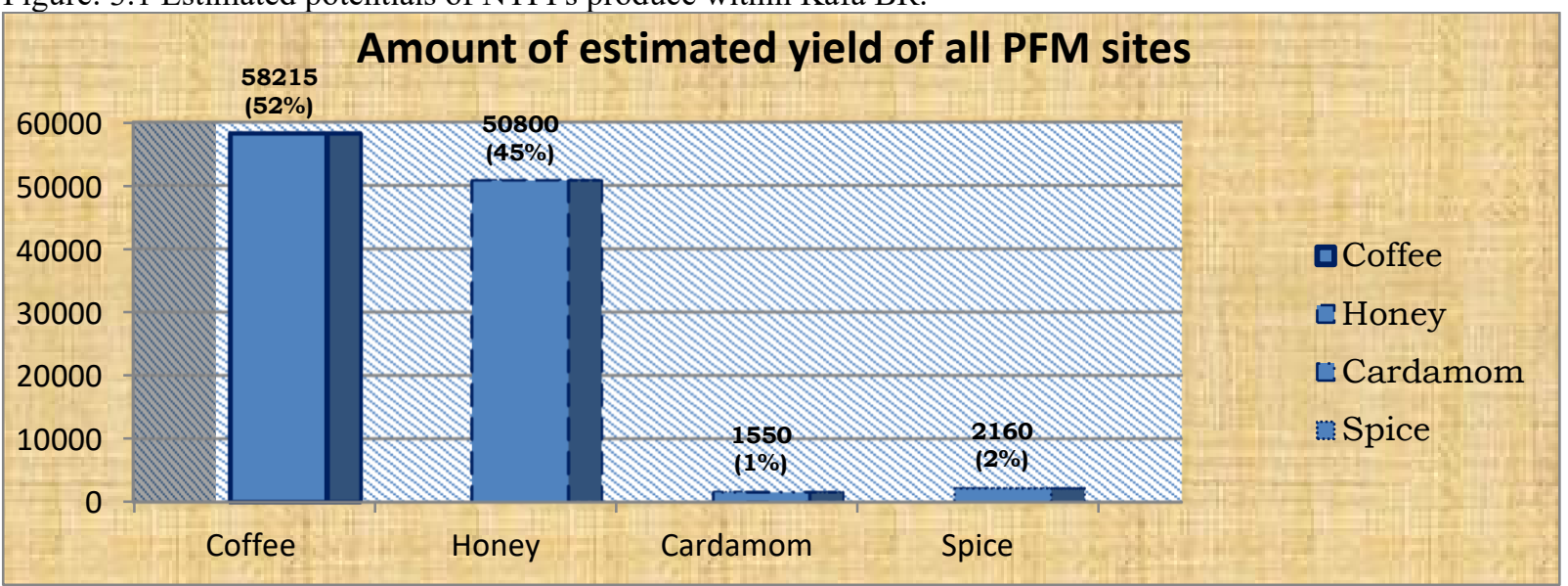

Source: Field Survey

As one can see from the figure above the estimated produce of both Cardamom and Spice was low, it was less estimated based on their previous experience where the resources were under intense population pressure due to its marketability at local and national level. 
Figure: 3.2. The estimated harvesting potential of NTFPs in each District.

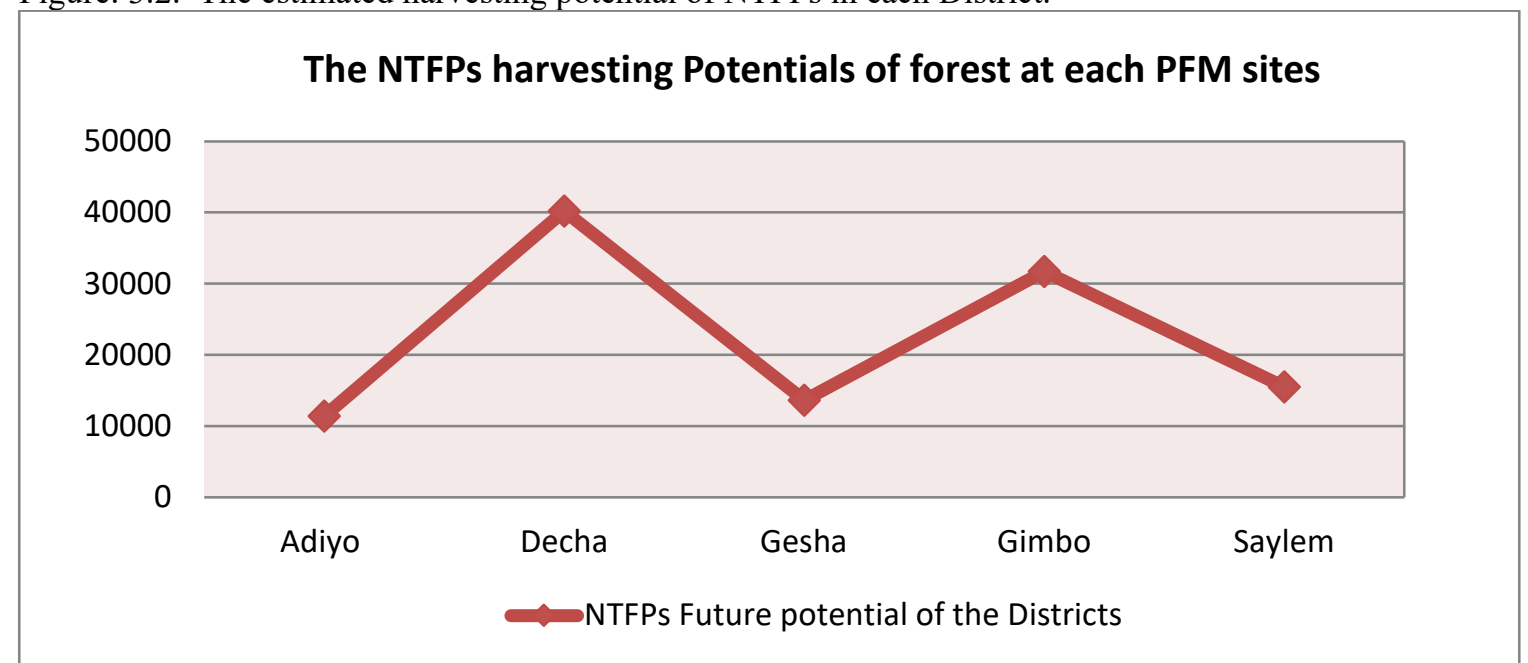

Source:- Field Survey

As portrayed above, annual estimation the FUGs planned to harvest NTFPs from the demarcated forest blocks of each PFM sites. Thus, the establishment of PFM site come with market link for resource potentials districts and plan for improved forest management.

The market link by Kafa forest Coffee Farmers Cooperative Union (KFCFCU) is the visible evidence in Kafa BR. In Kafa BR all PFM sites that has high potential of forest coffee harvest were members of KFCFCU, has international market chain at national and international level (KFCFCU, 2013).

The committee members of all PFM sites expressed that, they are searching for viable market for other produces and planning for optimizing their annual yields and management indeed.

\subsubsection{Generating Revenue to start up the PFM scheme}

The sustainability of forest based projects like PFM scheme in different areas and countries depend on the solution it brought to tackle deforestation and poverty and the financial implications it brings from the start (Winberg, 2010).

The goal of establishing PFM sites was primarily advancing the livelihoods of the societies in their local level via the natural resource management and gets benefitted from it while conserving the natural forest.

In Kafa BR, forests are the source of food, traditional medicine and source of power or fuel wood for rural households. These all are more of economical by substituting agricultural products and technological outputs. Gathering and sale of NTFPs can provide income to households (MoARD, 2013).

The study confirmed that the viable economic activity with visible change in the saved income of 1,112,375ETB among PFM sites within Kafa BR. Thus, with the establishment of PFM sites by PFM level financial building got strong and shown differences based on the performances of FUGs and the opportunities. The source of income of each site was proved found from three directions as clearly shown hereunder.

Table: 3.3 The amount of capital accumulation from different sources.

\begin{tabular}{|c|l|c|c|}
\hline No & Sources of income & Amount of income (ETB) & $\%$ \\
\hline 1 & Sales of NTFPs from the Forest under protection & 58,182 & 5.23 \\
\hline 2 & Compensation fees & $1,022,130$ & 91.89 \\
\hline 3 & Sale of illegally collected forest products & 13,593 & 1.22 \\
\hline 4 & Membership and penalty fees & 18,470 & 1.66 \\
\hline
\end{tabular}

Source:- Field Survey

As clearly indicated above PFM sites at their youth stage potentially legalized and powered to generate income to function the scheme:

1. To manage and generate income from NTFPs within demarcated forest site via advancing market link for the product even at initial years where most FUGs were rushing on forest development phase. Here forest user groups that have strongly committed executive committee collected high income from the sale of NTFPs.

2. The legal recognition of forest land gave use right for collecting compensation fees with road infrastructure development touching the demarcated forestland. The great part of this section is the governing power of FMP agreed between actors to optimize the PFM scheme.

3. In forest protection section the executive committee generates income from illegally collected NTFPs based on granted right from government through FMP. Here, beyond income collection the institutional strength 
in making decision on FMP implementation is regarded as promising and it indicated the future prospects of PFM scheme in Kafa BR.

4. In relation to effective implantation of FMP the commitment of executive committee goes up to penalizing less committed forest users. In addition to this in some PFM sites fee based membership registration equipped them with better chance to perform effectively so as to fulfill some office materials and other necessary equipment demanded for forest management.

\subsubsection{Institutional structure}

PFM relies on engaging local community and other stakeholders in the management of forest (Motuma et al, 2016). Intensive awareness creation, skill development training, establishment of local institution and transfer of management responsibility and use right to the organized local institution and use of indigenous knowledge are positive attributes of community involvement seen in PFM activities.

The establishment of PFM sites is realized up on the set-up PFM institution or organization and legal recognition. As describe above, income generation start up by some PFM sites, other sites the so called losers ${ }^{1}$, get motivated for the future. As a result in most PFM sites membership applications are coming and discussions are underway via general assembly meeting so as to accept or reject the application. This by itself is raising the organization of the FUGs. The presence of the project sites, with all their challenges, can be taken as a success. This is due to the fact that their very existences in the area and some activities they have performed have changed the attitude of the community towards conserving and protecting the forest area. "The participation by the community and the planned community development activity could be to the best of the forest conservation if implemented properly. In addition, the support the project had by the local leadership is a success factor for its implementation and acceptance in the project areas" (Girma, 2005).

Hence, PFM scheme come up with institutional structure in manageing and conserving the degrading forest resources of the country under Kafa BR through moblizing the mass without bais in respect to sex, age, religion and ethnic background. Moreover, the PFM scheme healed up the government plan and programs like "Green Revoulution" in its principles. For long years the national forest resource was degraded due low concern from concerned bodies particularly mobilizing the local people. In Kafa BR, after the establishment of PFM sites via shared responsibilities routine assignments in forest protection, forest development and controlled utilization actions that shown significant change all together can symbolizes the room for improved, sustainable and equitable forest management.

\subsubsection{Restoration of forest and microclimate}

During the field survey all the executive committees dully confirmed and I personally visited that since the establishment of PFM sites the forest ecology was highly healed-up and the air condition and streams were prolonged from its periodic die-up in their local condition". These conditions are the same in most sites as reports from most PFM sites come with the improvement of forest quality in terms of recovering biodiversity, higher seedling survival and improved water quality as another success with the establishment of PFM sites (KFCFCU, 2013).

This indicates the FUGs got some awareness on global issues and participating for the solution by their part. This is global participation in general and will be the national asset for achieving the commitment to reduce carbon emission from deforestation. Thus, the establishment of PFM sites was not only for local value.

In addition to these in most PFM sites due to the restoration of forest ecology some endangered animals proved locally vanished were started emerging as confirmed by FUGs. This is to say the forest was now possibly protected the wildlife as it was in a state of protection by FUGs, no illegal hunters entrance within the forest under Kafa BR.

\subsection{Contests within PFM sites established within Kafa BR and possible intervention}

After the establishment of PFM sites with special natural setup and legalized forest management plan, there has some contests seen as the greatest bottle neck on internationally legalized Kafa forest coffee Biosphere Reserve (MoARD F. a., 2010) (Forestry, 1996). On the basis of confirmed result some of contests include the following;

\subsubsection{Irregularity of PFM performance against forest management plan (FMP)}

In most sites irrespective of PFM site establishment and legal use right recognition (Alemayehu et al, 2015) the FMP commonly prepared and agreed among actors was not yet practiced on its pace. Here, alarm seeking, weak and passive executive committees and report based communication from government agents make some PFM sites too late. As some committee members stressed that in FMP implementation gap the government agents were not helping us in securing forest protection in addition to internal conflict of interest on forest protection and utilization need. This resulted low performance of forest users on forest protection and high need for utilization; as confirmed from forest executive implementation committee members' reflection.

Table: 3.4 Level of communication and cooperation with different actors

\footnotetext{
${ }^{1}$ Losers - in this case refers to the one who were not the members of FUGs by plan or ready to accept membership.
} 


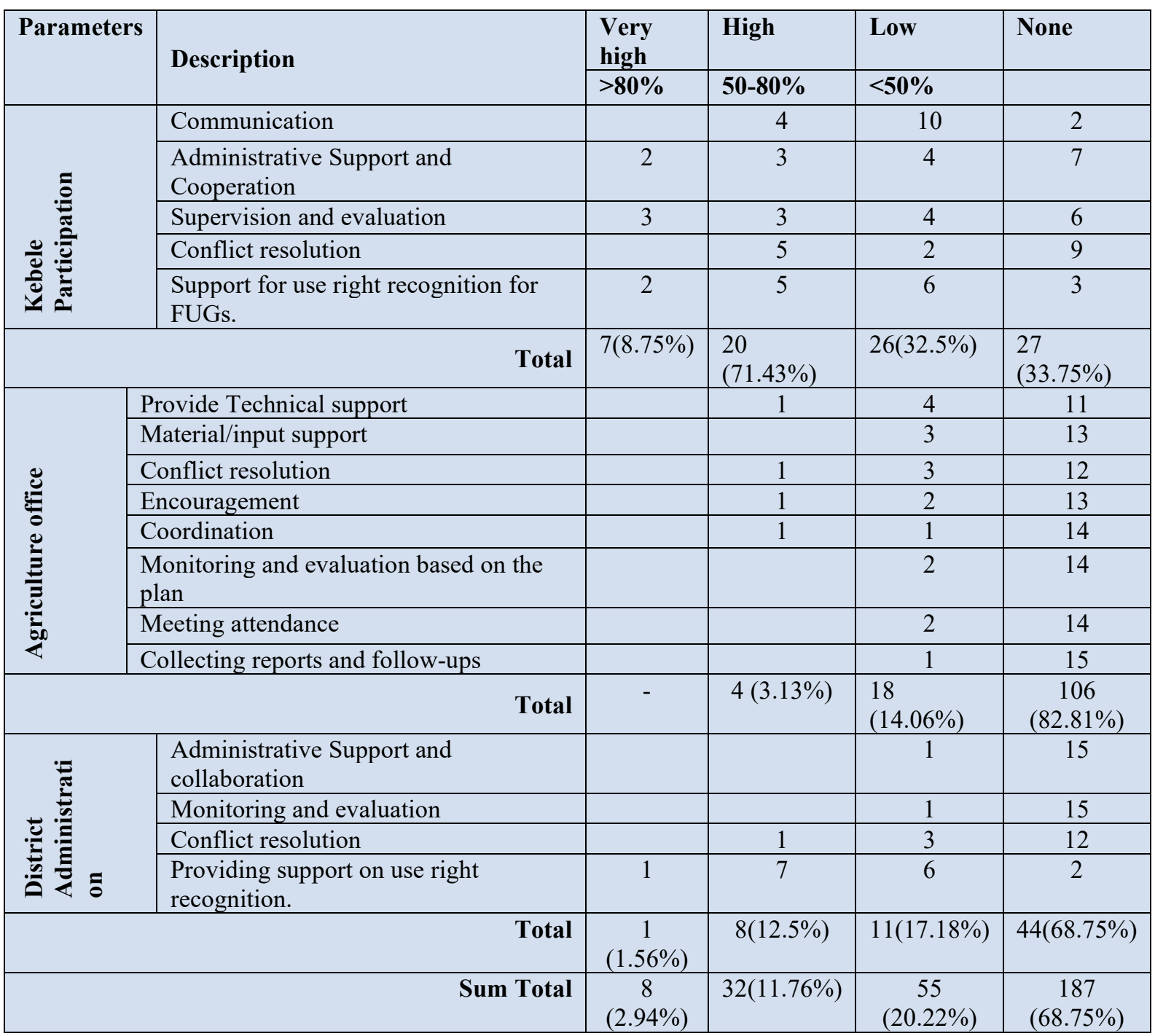

Source:- Befikadu M.(2019)

From this table one can see that forest management plan implementation was abused due to lack of integrative communication among actors responsibly agreed to make FMP significantly practical. Hence, backing the institutional organization through managerial and material aid is highly demanding with effective integration to sustain the promises of PFM scheme.

3.2.2. Low understanding of the rationale, principles and practice of PFM scheme among government staff; In the phase of PFM site establishment and legalizing stage the agreement and promising interest of government agents from local level to zonal was strong based on the confirmation letters and verified contractual agreements among actors to optimize FMP at each PFM sites established within Kafa BR.

The plan dictates governmental organizations in their respective position as the main actors in which they are envisaged to plan and play their role for forest development by accelerating the FUGs, which is the great opportunity for the each District in particular and for the nation in general as natural forest development via participatory forest management approach. The FMP agreed between actors contain clear rationale, principles and practical responsibilities of each party (Alemayehu et al, 2015). Here, as confirmed as one bottle neck of each PFM site during field survey and reflection workshop most of government agents put their signature by representing either their district or respective departments get passive in practicing the word of agreement.

As the result of poor support of government agents great interest of forest use plan and low interest on protection with pressure from illegal users harming the forest for timber, firewood, charcoal and agricultural land expansion; highly challenged the performance of FMP.

\subsubsection{Projection of FMP implementation irregularities}

As indicate $\mathrm{d}$ above, in response to weak support from government agents and increasing interest from illegal users and excessive uses beyond development shows poor commitment from executive committee. However, within irregular functioning of FMP almost all actors were projecting the failures of PFM scheme. In the FMP every detail were specified and forest users were legally shared activities and formed executive committees as well on 
forest development, protection and utilization. Accordingly, within Kafa BR 2.75\% forest development, $75 \%$ forest protection and absolute utilization performance indicates the level irregularities against FMP highly threaten the long term perspectives of PFM scheme.

Therefore, managing the performance of each stakeholder needs the involvement government agents according to the FMP. After this the practices of FUGs needs management and material support as well.

\section{Conclusion and Recommendations}

The establishment of Participatory Forest Management (PFM) within Kafa Biosphere Reserve (BR) with legal use right recognition to community through integrated forest management plan (FMP) among responsible stakeholder brought common responsibility on state resources in general and forest in particular. Hence, in this paper, after recognizing the role of PFM scheme within five districts mandated fore 16 PFM sites in Kafa zone. Ironic to this the practical implementation of FMP has got variability even though it was welcomed and recognized among different actors on forest management.

Accordingly, the study concluded that the established 16 PFM sites have both promises and some contests for the community special to Kafa BR. Plan based forest management scheme with agreed and shared responsibility arose the integration of rural community as forest user group, local government agents and interested NGOs to secure about 11,539ha of forest with plenty of Non-Timber Forest Products (NTFPs). In addition to this, identification of forest potential NTFPs resources to generate revenue to secure the sustainability of PFM scheme by strengthening the institutional coordination for common goal and restoration of forest biodiversity and microclimate of the region. However, these valued promises lacks uniformity among PFM sites due to commitment gap among executive committee members of FUGs, neglect from government agents, and low understanding of the rational, principles and practices of the PFM scheme.

Therefore, so as to optimize the promises and visible significances of PFM scheme revising FMP implementation actions against performances and taking action is demanding with full of commitment among FUGs. The government agents who have better skills and knowledge should offer managerial and material support to fill the visible gaps on forest management.

\section{Bibliography}

Alemayehu et al. (2015). Performance of participatory forest management in Ethiopia: institutional arrangement versus local practices. Critical Policy Studies, 28.

Ben DeVries et al. (2012). MONITORING THE IMPACT OF REDD+ IMPLEMENTATION IN THE UNESCO KAFA BIOSPHERE RESERVE, ETHIOPIA. Sensing a Changing World 2012, 1-5.

Forestry. (1996). Participatory Forest Management Policy and Practice in South Africa. White Paper on Sustainable Forest Development, 1996 . South Africa, South Africa: Minstry of Forest.

Girma, M. (2005). Assessment of Institution's Capacity Involved in the Conservation of Coffea Arabica in the Montane Rainforests of Southwest Ethiopia. MA.Thesis . Addis Ababa, Ethiopia: Addis Ababa University.

GOBEZE. (2009). Participatory forest management and its impacts on livelihoods and forest status: the case of Bonga forest in Ethiopia. International Forestry Review Vol.11(3), 346.

KFCFCU. (2013). Ethiopia Participatory Forest Management (PFM) Project Report. Bonga, Ethiopia.

MoARD. (2013). NON-TIMBER FOREST PRODUCTS DEVELOPMENT TRAINING MANUALS SERIES. Addis Ababa, Ethiopia: Minstry of Agriculture Natural Resource Management Directorate.

MoARD, F. a. (2010). Policy, Strategy and Proclamation on Forest Development, Conservation and Utilization. Ethiopia, Ethiopia: Central Printing press.

Motuma et al. (2016). In-situ Conservation of wild forest coffee - Exploring the Potential of Participatory Forest Management in South-West Ethiopia.

Mulugeta et al. (2015). Making forest conservation benefit local coMMunities:participatory forest Management in ethiopia. Addis Ababa: FARM AFRICA.

NABU. (2010). Kafa Biosphere Reserve; South-West Ethiopia. Addis Ababa, Ethiopia.

Tesfaye, Y. (2011). Participatory Forest Management for Sustainable Livelihoods in the Bale Mountains, Southern Ethiopia. Uppsala: Swedish University of Agricultural Sciences.

Winberg. (2010). Winberg, E. (2010, June). Participatory Forest Management in Ethiopia, Practices and Experiences. Food and Agriculture Organization Sub Regional Office for Eastern Africa (SFE), . Addis Ababa, Ethiopia: FAO.

Yonas. (2005). Yonas, A. (2005, July). Community values and Natural Resource Management. MA thesis . In A. A. University. Addis Ababa, Ethiopia. 